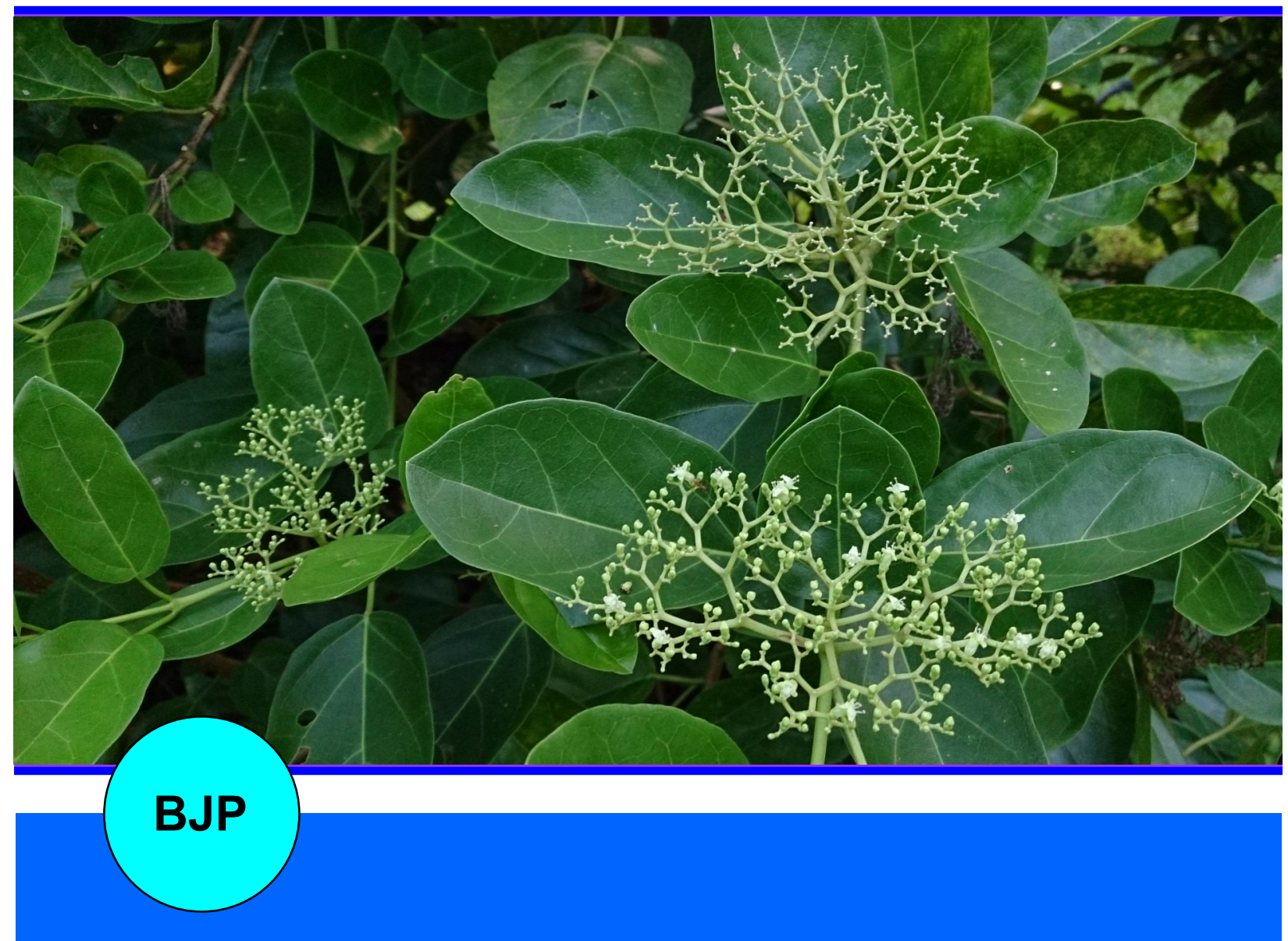

Bangladesh Journal of Pharmacology

Research Article

Cardiac stimulant activity of bark and wood of Premna serratifolia 


\title{
Cardiac stimulant activity of bark and wood of Premna serratifolia
}

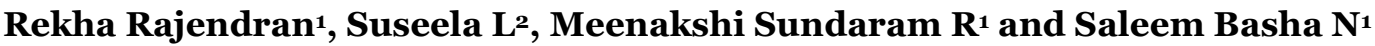 \\ ${ }^{1}$ Department of Pharmacognosy, Mohamed Sathak A. J. College of Pharmacy, Medavakkam, Chennai 600 119; \\ ${ }^{2}$ Department of Pharmacognosy, Madras Medical College, Chennai 600 003, India.
}

\begin{tabular}{|c|c|}
\hline \multicolumn{2}{|l|}{ Article Info } \\
\hline Received: & 5 July 2008 \\
\hline Accepted: & 20 July 2008 \\
\hline Available Online: & 27 July 2008 \\
\hline \multicolumn{2}{|c|}{ DOI: 10.3329/bjp.v3i2.952 } \\
\hline \multicolumn{2}{|c|}{$\begin{array}{l}\text { Cite this article: } \\
\text { Rajendran R, Suseela L, Sundaram R } \\
\text { M, Basha NS. Cardiac stimulant activ } \\
\text { ity of bark and wood of Premna serrat } \\
\text { ifolia. Bangladesh J Pharmacol. } 2008 \\
\text { 3: 107-13. }\end{array}$} \\
\hline
\end{tabular}

\begin{abstract}
Premna serratifolia Lin., (Verbenaceae) contains alkaloids and iridoid glycoside and is believed to prevent cardiovascular disease. The stem-bark and stemwood were extracted with $95 \%$ ethanol and distilled water. These extracts were screened for their effects by "Isolated Frog Heart Perfusion Technique" and biochemical parameters in heart tissue and serum of albino rats after administering the extracts for 7 days. The ethanol extract produced significant positive ionotropic and negative chronotropic actions similar to that of digoxin on frog heart and its effect was in hibited by nifedipine but not by propranolol. A significant decrease in membrane $\mathrm{Na}^{+} \mathrm{K}^{+} \mathrm{ATPa} e$ and $\mathrm{Mg}^{2+} \mathrm{ATPase}$ and an increase in $\mathrm{Ca}^{2+}$ ATPase further confirmed its cardiotonic activity. Aqueous extract produced positive ionotropic and chronotropic effects similar to that of adrenaline and its effect was antagonized by propranolol and nifedipine. The results suggest that the ethanol extract produced cardiotonic effect and the aqueous extract produced $\beta$-adrenergic effect.
\end{abstract}

\section{Introduction}

Cardiovascular disease incurs a greater economical constraint than any other illness especially in the developing countries. It is the most common cause of death by the year 2020. The risk factors for heart disease are family history, sex, increased lipid levels, diabetes mellitus, hypertension, obesity and cigarette smoking. There is overwhelming evidence indicating hypercholesterolemia and other lipid abnormalities as major risk factors in the development of atherosclerosis and coronary heart disease. Therefore, cardiovascular disease becomes a very common problem in the affluent societies related to their life style (Trivedi, 2004).

In developed countries, coronary vascular diseases now constitute the principal cause of human mortality. Not surprisingly, therefore, this is an intensive research, not entirely devoted to treatment, but also to the prevention of these diseases. Many factors affect the complex regulation of the heart and there is a large group of drugs which will affect the heart's performance, often in a manner not directly associated with the heart muscle itself. However, the therapeutic use of drugs for the treatment of the failing heart is confined to a small group of glycosides that act directly on the heart muscle (Evans, 1996). Cardiovascular disorder leads to variety of pathological changes including endothelial, pulmonary, hepatic, renal, endocrine, skeletal muscle abnormalities and the state of multi-organ impairment (Poole-Wilson et al., 1997). Cardiac glycosides and catecholamine have been used 
as the main therapeutic drugs in the treatment of coronary heart disease (Kitada et al., 1987). There is no evidence that digitalis prolongs survival of coronary heart disease patients (Tripathi, 2001), major limitations in the use of cardiac glycosides are low margin of safety, inability to retard the process which caused the heart to fail and intoxification are well documented (Beller et al., 1971). Catecholamine use is limited by its, insufficient differentiation between positive ionotropic and chronotropic actions, potential arrthythmogenic properties, tachyphylaxis due to receptor down-regulation and causes a severe oxidative stress in the myocardium through free radical formation (Kitada et al., 1987). There are so many popular herbs used in traditional practices to cure cardiovascular problems. Premna serratifolia Lin., is having an important place in such cardiovascular medicinal herbs (Yoganarasimhan, 2000) and its synonym is Premna integrifolia Lin. It is known as "Munney" in Tamil, "Agnimantha" in Ayurveda and used as cardiotonic, antibiotic, antihyperglycemic (Natkarni, 1976). It is widespread throughout Micronesia and tropical Asia. Root forms an ingredient in well known Ayurvedic formulation "Dasamula" for variety of affections (Anonymous, 1972). It has shown anticoagulant activity (Gopal and Purushothaman, 1984) and the decoction exhibited anti-inflammatory and antiarthritic activity (Rathore et al., 1977). However, its cardiotonic activity has not been investigated still now. Hence it was considered to evaluate the cardioactive potential and its mechanism of action.

\section{Materials and Methods}

\section{Preparation of extracts}

Fresh stem-bark and stem-wood of P. serratifolia Lin., was collected from The Indian Medical Practitioners Co-operative Pharmacy and Stores garden, Chennai, Tamil Nadu. Plant material was identified and authenticated (PARC/2007/71) by a Botanist, Dr. P. Jayaraman, Plant Anatomical Research Centre, Chennai. Materials were cleaned with water and dried in the shade until a constant weight was obtained. It was extracted with 95\% ethanol and double distilled water in a Soxhlet extractor. Extracts were concentrated; the percentage yield for ethanol and aqueous extracts were 7.9 and $7.7 \%$. For pharmacological studies, since the ethanol extract was not soluble in water, it is suspended in 5\% gum acacia and aqueous extract was being water soluble, hence an aqueous solution was used.

\section{Drugs and chemicals}

Digoxin, adrenaline, propranolol and nifedipine were procured from Government General Hospital, Chennai. All other chemicals used were of higher quality analytical grade.

\section{Animals}

Frogs of Rana hexadactyla species (procured from animal house of Madras Medical College) and male Wister albino rats $(200 \mathrm{~g})$ housed in cages at $27 \pm 2^{\circ} \mathrm{C}$

on a 12 hours light/dark cycle was used. The animals were fed with food and water ad libitum. The animals were maintained as per the norms of CPCSEA (6/243/ CPCSEA/2007) and cleared by CPCSEA and institutional ethics committee (Madras Medical College).

\section{Phytochemical screening}

Ethanol extract showed positive reaction for alkaloids, glycosides, flavonoids and steroids whereas the aqueous extract showed positive reaction for alkaloids, glycosides and phenolic compounds. HPTLC profile of ethanol extract showed 10 peaks in the solvent system of $n$-hexane: ethylacetate $(3: 1)$ at $260 \mathrm{~nm}$ and aqueous extract showed 7 peaks in the solvent system of chloroform: methanol: water (7:2.6:0.4) at $260 \mathrm{~nm}$.

\section{Isolated frog heart perfusion technique (Muralidharan and Dhananjayan, 2004)}

Frogs were pithed and heart was exposed. The inferior vena cava was traced and cannulated for perfusing the heart with the frog's Ringer solution. (Composition of frog Ringer solution in mmol: NaCl-110; KCl-1.9; $\mathrm{CaCl}_{2}$ -1.1; $\mathrm{NaHCO}_{3}-2.4 ; \mathrm{NaH}_{2} \mathrm{PO}_{4}-0.06$; Glucose-11.1). The basal cardiac contraction was recorded on a smoked kymographic drum after the administration of frog Ringer's solution and 5\% gum-acacia. Administration of gum acacia was done to see that it did not contribute to the effects of extracts. Drugs and extracts were administered through the cannula. The average heart rate and the contraction amplitude were recorded on a smoked kymographic drum and it was found to be 64 beats/min and $8 \mathrm{~mm}$ respectively. The effects obtained with the drugs and extracts were transposed to the 
respective percentage of the basal values. Graded doseresponse was recorded for each extract and the dose which caused the maximum effect was chosen as the experimental dose. The frog heart was washed with the Ringer solution after every administration of extracts and drugs till it was brought back to the normal state. The frog heart was perfused with propranolol, at $30 \mu \mathrm{M}$ concentration in frog Ringer solution for $60 \mathrm{sec}$ followed by the administration of extracts and the recording were noted. Nifedipine, at $28.8 \mu \mathrm{M}$ concentration in frog Ringer solution was administered for $60 \mathrm{sec}$ followed by extracts and the recordings were noted.

\section{Biochemical studies in Wistar albino rats}

Animals were randomized into 3 groups of 6 rats each. Group I was treated with gum acacia suspension i. p. for 7 days which served as control. Group II and III animals were treated with ethanol and aqueous extracts at a dose of $200 \mathrm{mg} / \mathrm{kg}$ (approximately 1/10 of the $\mathrm{LD}_{50}$ ) body weight i. p. for 7 days. On $8^{\text {th }}$ day, all the animals from 3 groups were sacrificed. Blood was collected by cardiac puncture and heart-tissue was collected and serum was separated from the blood. The heart was washed in ice-cold saline and $100 \mathrm{mg}$ of tissue was weighed and homogenized in chilled $0.1 \mathrm{M}$ Tris- $\mathrm{HCl}$ Buffer ( $\mathrm{pH} 7$ ) and the homogenate was used for the assay of $\mathrm{Na}^{+} \mathrm{K}^{+} \mathrm{ATPase}$ (Bonting, 1970), $\mathrm{Ca}^{2+}$ ATPase (Hjerten and Pan, 1983) and $\mathrm{Mg}^{2+}$ ATPase (Ohinishi et al., 1982). Serum and homogenized samples were assayed for the clinical marker enzymes like CPK (Okinaka et al., 1961), LDH (King, 1965a), AST and ALT (King, 1965b).

\section{Histopathological studies}

A portion of heart from each group was stored in $10 \%$ formalin, for processing and sectioning. By following routine histological techniques, these samples were put into paraffin and serial cross sections of $5 \mu \mathrm{m}$, which were taken from tissue blocks stained with hematoxylin and eosin. The preparations were evaluated under a photomicroscope and were photographed.

\section{Statistical analysis}

Results were expressed as mean \pm standard error for 6 animals in each group. Differences between groups were assessed by one-way ANOVA using Bonferroni test. Post hoc testing was performed for inter-group comparisons using the least significance difference test. $\mathrm{p}<0.05$ have been considered as significant.

\section{Results}

Ethanol extract produced significant positive ionotropic and negative chronotropic effects similar to that of digoxin on frog heart and it is indicated by an increase in the force of contraction (Table I) and a decrease in the heart rate (Table II). This cardiotonic effect of the ethanol extract was not antagonized by propranolol, whereas nifedipine treatment significantly reduced the cardiotonic effect. There was a significant decrease in membranous $\mathrm{Na}^{+} \mathrm{K}^{+}$ATPase and $\mathrm{Mg}^{2+}$ ATPase $(\mathrm{p}<0.05)$ and an increase in $\mathrm{Ca}^{2+}$ ATPase (Table III) when compared with that of the control and this further confirmed its cardiotonic effect.

Table I

Effect of Premna serratifolia extract on force of contraction using isolated frog heart perfusion technique

\begin{tabular}{|c|c|c|c|c|c|c|}
\hline & \multicolumn{2}{|c|}{ Frog Ringer } & \multicolumn{2}{|c|}{$\begin{array}{l}\text { Frog Ringer + propranolol } \\
\qquad(1 \mathrm{mg} / \mathrm{mL})\end{array}$} & \multicolumn{2}{|c|}{$\begin{array}{l}\text { Frog Ringer + nifedipine } \\
\qquad(1 \mathrm{mg} / \mathrm{mL})\end{array}$} \\
\hline & $\begin{array}{l}\text { Force of contraction } \\
(\mathrm{mm})\end{array}$ & $\begin{array}{c}\text { Change } \\
(\%)\end{array}$ & $\begin{array}{l}\text { Force of contraction } \\
(\mathrm{mm})\end{array}$ & $\begin{array}{c}\text { Change } \\
(\%)\end{array}$ & $\begin{array}{l}\text { Force of contraction } \\
(\mathrm{mm})\end{array}$ & $\begin{array}{c}\text { Change } \\
(\%)\end{array}$ \\
\hline Digoxin & $14.1 \pm 0.40^{\text {ae }}$ & 76.3 & - & - & $10.3 \pm 0.7 \mathrm{ae}$ & 28.8 \\
\hline Adrenaline & $21.5 \pm 0.56^{\mathrm{a} b d}$ & 168.8 & $13.6 \pm 0.3^{\mathrm{ae}}$ & 70.0 & & - \\
\hline Ethanol extract & $14.8 \pm .30$ a ce & 75.4 & $14.2 \pm 0.4^{\mathrm{ae}}$ & 77.0 & $10.6 \pm 0.5^{\mathrm{ae}}$ & 32.5 \\
\hline Aqueous extract & $20.5 \pm 0.32^{a}$ bd & 156.3 & $16.1 \pm 0.7$ acd & 101.3 & $13.8 \pm 0.7 \mathrm{abd}$ & 72.5 \\
\hline F value & 196.219 & & 63.836 & & 19.448 & \\
\hline P value & $<0.001$ & & $<0.001$ & & $<0.001$ & \\
\hline
\end{tabular}




\section{Table II}

\section{Effect of Premna serratifolia extract on heart rate using isolated frog heart perfusion technique}

\begin{tabular}{|c|c|c|c|}
\hline & \multicolumn{3}{|c|}{ Heart rate (per min) } \\
\hline & Frog Ringer & $\begin{array}{l}\text { Frog Ringer + propranolol } \\
(1 \mathrm{mg} / \mathrm{mL})\end{array}$ & $\begin{array}{l}\text { Frog Ringer + nifedipine } \\
\qquad(1 \mathrm{mg} / \mathrm{mL})\end{array}$ \\
\hline Digoxin & $58.6 \pm 0.4^{\text {ce }}$ & - & $55.0 \pm 0.6^{d}$ \\
\hline Adrenaline & $136.3 \pm 0.8^{\mathrm{abde}}$ & $107.0 \pm 0.7 \mathrm{ad}$ & - \\
\hline Ethanol extract & $57.8 \pm 0.7$ ce & $59.5 \pm 0.3^{\text {ce }}$ & $37.6 \pm 0.5^{\text {abe }}$ \\
\hline Aqueous extract & $108.2 \pm 0.5^{\mathrm{abcd}}$ & $96.3 \pm 0.8^{\mathrm{ad}}$ & $55.8 \pm 1.1^{\mathrm{d}}$ \\
\hline F value & 246.27 & 96.30 & 13.22 \\
\hline$P$ value & $<0.001$ & $<0.001$ & $<0.001$ \\
\hline
\end{tabular}

\section{Table III}

\section{Effect of the extracts of Premna serratifolia extract on membrane bound phosphatases in rats}

\begin{tabular}{|c|c|c|c|}
\hline Groups & $\mathrm{Na}^{+} \mathrm{K}^{+} \mathrm{ATPase}$ & $\mathrm{Ca}^{2+}$ ATPase & $\mathrm{Mg}^{2+} \mathrm{ATPase}$ \\
\hline Control & $0.5 \pm 0.02$ & $0.2 \pm 0.01$ & $0.4 \pm 0.01$ \\
\hline Ethanol extract & $0.4 \pm 0.011^{a^{*} b^{*}}$ & $0.4 \pm 0.01 \mathrm{a}^{*} \mathrm{~b}^{*}$ & $0.3 \pm 0.01^{a^{*} b^{*}}$ \\
\hline Aqueous extract & $0.5 \pm 0.01^{b^{*} c^{*}}$ & $0.3 \pm 0.01 b^{*} c^{*}$ & $0.4 \pm 0.004 b^{b^{*} c^{*}}$ \\
\hline F value & 25.57 & 56.017 & 19.531 \\
\hline$p$ value & $<0.001$ & $<0.001$ & $<0.001$ \\
\hline
\end{tabular}

Table IV

\section{Effect of the extracts of Premna serratifolia $\mathbf{n}$ the clinical marker enzymes in rats}

\begin{tabular}{lcccccc} 
Marker enzymes & \multicolumn{2}{c}{ Control } & \multicolumn{2}{c}{ Ethanol extract } & \multicolumn{2}{c}{ Aqueous extract } \\
\cline { 2 - 7 } & Heart & Serum & Heart & Serum & Heart & Serum \\
Creatinine phosphokinase & $0.6 \pm 0.01$ & $0.6 \pm 0.01$ & $0.6 \pm 0.01$ & $8.9 \pm 0.01$ & $0.6 \pm 0.01$ & $9.0 \pm 0.01$ \\
Lactate dehydrogenas & $2.9 \pm 0.03$ & $2.9 \pm 0.03$ & $2.9 \pm 0.03$ & $5.6 \pm 0.02$ & $3.0 \pm 0.05$ & $5.2 \pm 0.03$ \\
Alanine transaminase & $0.1 \pm 0.01$ & $0.1 \pm 0.01$ & $0.1 \pm 0.01$ & $0.6 \pm 0.01$ & $0.1 \pm 0.01$ & $0.6 \pm 0.01$ \\
Aspartate transaminae & $0.2 \pm 0.01$ & $0.2 \pm 0.01$ & $0.2 \pm 0.01$ & $0.5 \pm 0.01$ & $0.2 \pm 0.01$ & $0.5 \pm 0.01$
\end{tabular}

$\mathrm{n}=6$; values are expressed as mean $\pm \mathrm{SE}$; Enzyme units- for heart creatinine phosphokinase: $\mu$ moles of phosphorus liberated/min/mg protein, For serum creatinine phosphokinase: $\mu$ moles $\times 10^{-3}$ of phosphorus liberated $/ \mathrm{min} / \mathrm{mg}$ protein; Lactate dehydrogenase: $\mu \mathrm{moles} \times 10^{-1}$ of pyruvate liberated $/ \mathrm{min} / \mathrm{mg}$ protein. Aminotransferases: $\mu$ moles $\times 10^{-2}$ of pyruvate liberated $/ \mathrm{min} / \mathrm{mg}$ protein

Aqueous extract produced a significant positive ionotropic and positive chronotropic actions similar to that of Adrenaline on frog heart and it is indicated by an increase in the force of contraction and the heart rate. Propranolol and nifedipine antagonized the effect of the aqueous extract. No significant changes were observed in membrane bound phosphatase in rat.

Both the extracts do not produce any significant changes in the levels of CPK, LDH, AST and ALT in heart and in serum samples when compared to that of the control (Table IV). Therefore, it indicated that both 
the extracts do not altered the physiological conditions of the heart.

Histopathological studies of both the extracts do not produce any significant pathological changes in the heart when compared to that of the control (data not shown) and therefore it is indicated that both the extracts do not altered the physiological conditions of the heart.

\section{Discussion}

Ethanol extract produced cardiotonic effect, which was characterized by positive ionotropic and negative chronotropic actions. This effect was not significantly blocked by propranolol whereas nifedipine, antagonized the effect significantly. Cardiac enzyme profile indicates that the ethanol extract exhibited powerful cardiotonic like activity which manifested as a result of general decrease in the activity of $\mathrm{Na}^{+} \mathrm{K}^{+} \mathrm{ATPase}$ and $\mathrm{Mg}^{2+} \mathrm{ATPase}$ and an increase in $\mathrm{Ca}^{2+}$ ATPase.

Most important electrolytes like sodium, potassium, calcium, magnesium and bicarbonate provide inorganic chemicals for biochemical processes as well as act at the cell membrane to allow transmission of electrochemical impulse in nerve and muscle fibers (Kokko and Tannen, 1990). The intracellular cation plays a significant role in the regulation of normal physiology and biochemistry of cardiac and smooth muscles. Dysregulation of these processes is an important factor in the genesis of various serious arrhythmias (Bassett et al., 1997). Various studies have reported inhibition of $\mathrm{Na}^{+} \mathrm{K}^{+}$ATPase activity during cardiovascular problems (Less, 1991). This inhibition of $\mathrm{Na}^{+} \mathrm{K}^{+}$ATPase is similar to the action of cardiac glycosides (Akera and Brody, 1997). Cardiac glycosides are specific and unique inhibitors of $\mathrm{Na}^{+} \mathrm{K}^{+}$ATPase at normal concentrations (10-8 to $\left.10^{-9} \mathrm{M}\right)$ (Goto et al., 1992). $\mathrm{Na}^{+} \mathrm{K}^{+}$ATPase inhibition by cardiac glycosides leads ultimately to increase intracellular $\mathrm{Ca}^{2+}$ concentrations through $\mathrm{Na}^{+} / \mathrm{Ca}^{2+}$ exchange and an associated increase in slow inward $\mathrm{Ca}^{2+}$ current (Wang et al., 2002) as well as in transient $\mathrm{Ca}^{2+}$ current (McGarry and Williams,

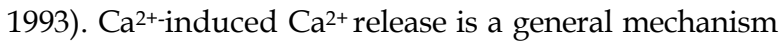
that most cells use to amplify $\mathrm{Ca}^{2+}$ signals (Wang et al., 2002). In heart cells, this mechanism is operated between voltage-gated L-type calcium channels (LCCs) in the plasma membrane and calcium release channel in the sarcoplasmic reticulum (Fabiato, 1985). Nifedipine is a LCC antagonist (Wang et al., 2002). Since nifedipine, blocks the cardiotonic action of the ethanol extract significantly, the extract might have produced its action by opening the voltage sensitive slow $\mathrm{Ca}^{2+}$ channel. In connection with the cardiotonic effects observed one could see a relationship that exists between the inhibitory levels of the activities of $\mathrm{Mg}^{2+}$ ATPase and $\mathrm{Na}^{+} \mathrm{K}^{+}$ATPase (Chen et al., 1992). The significant rise in the level of activity of $\mathrm{Ca}^{2+} \mathrm{ATPase}$ might be due to the rise of cytosolic $\mathrm{Ca}^{2+}$ (Kelly and Smith, 1996). Therefore this cardiotonic action of the ethanol extract might be attributed to the phytoconstituents present in it.

Aqueous extract produced positive chronotropic and positive ionotropic effects which were antagonized by propranolol indicating that these might have been mediated through $B$-adrenergic receptors. Nifedipine also blocks the action of the aqueous extract.

CPK is found in high concentration in skeletal muscle, myocardium and brain but not found in liver and kidney, small amounts are found in lungs not found in RB cells and its level is not affected by hemolysis. It appears to be a sensitive measure of myocardial infarction. $\mathrm{LDH}$ has gained much clinical interest recently and measurement of its activity in blood is considered useful in the diagnosis of certain cardiovascular disease conditions. AST level increase markedly in conditions of extensive damage to muscle especially cardiac muscles. Estimation of this enzyme is widely sought for, to confirm diagnosis of myocardial infarction. In pathological conditions, the enzymes such as CPK, LDH, AST and ALT leak from the necrotic heart cells to the serum, which are important measures of cardiac injury. These enzymes are not specific for myocardial injury individually; however, evaluation of these enzymes together may be an indicator of myocardial injury (Al-Shabanah et al., 1998; Chopra et al., 1995). Levels of CPK, LDH, AST and ALT of ethanol and aqueous extracts do not changed when compared to that of the control both in the serum and also in the heart. Therefore, it confirms that both the extracts does not altering the physiological conditions of the heart when given at the dose of $200 \mathrm{mg} / \mathrm{kg}$ body weight. 


\section{Acknowledgement}

Authors would like to thank the Department of Pharmacognosy and Pharmacology, Madras Medical College, Chennai, for providing the necessary facilities for the completion of the work.

\section{References}

Al-Shabanah O, Mansour M, El-Kashef H, Al-Bekairi A. Captopril ameliorates myocardial and hematological toxicities induced by adriamycin. Biochem Mol Biol Int. 1998; 45: 419-27.

Anonymous. The wealth of India - Dictionary of Indian raw materials and industrial products - Raw Materials. Vol. 8. New Delhi, Council of Scientific and Industrial Research, 1972, p 240.

Akera T, Brody TM. The role of $\mathrm{Na}^{+} \mathrm{K}^{+} \mathrm{ATPase}$ in the ionotropic action of digitalis. Pharmacol Rev. 1977; 29: 187220 .

Beller GA, Smith TW, Abelmann WH, Haber E, Hood WB Jr. Digitalis intoxication: A prospective clinical study with serum level correlations. N Engl J Med. 1971; 284: 989-97.

Bassett AL, Chakko S, Epstein M. Are calcium antagonists proarrhythmic? J Hypertens. 1997; 15: 915-23. http:// dx.doi.org/10.1097/00004872-199715090-00001

Bonting SL. Sodium-potassium activated adenosine triphosphatase and cation transport. In: Membrane and ion transport. Bittar EE (ed). London, Wiley-Interscience, 1970.

Chen CL, Sangiah S, Patterson E, Berlin KD, Garrison GL, Dunn W, et al. Effects of BRB-I-28, a novel antiarrhythmic agent and its derivatives on cardiac $\mathrm{Na}^{+} \mathrm{K}^{+}$ATPase, $\mathrm{Mg}^{2+} \mathrm{ATPase}$ activities and contractile force. Res Commu Chem Pathol Pharmacol. 1992; 78: 3-16.

Chopra S, Pillai KK, Husain SZ, Giri DK. Propolis protects against doxorubicin-induced myocardiopathy in rats. Exp Mol Pathol. 1995; 62: 190-98. http://dx.doi.org/10.1006/ exmp.1995.1021

Evans WC. Pharmacognosy. 14 ${ }^{\text {th }}$ ed. London, WB Saunders Company Ltd., 1996, pp 229-493.

Fabiato A. Time and calcium dependence of activation and inactivation of calcium-induced release of calcium from the sarcoplasmic reticulum of a skinned canine cardiac Purkinjee cell. J Gen Physiol. 1985; 85: 247-89. http:// dx.doi.org/10.1085/jgp.85.2.247

Gopal RH, Purushothaman KK. Effect of plant isolates on coagulation of blood: An in vitro study. Bull Med Ethnobot
Res. 1984; 5: 171-77.

Goto A, Yamada K, Yagi N, Yoshioka M, Sugimoto T. Physiology and pharmacology of endogenous digitalislike factors. Pharmacol Rev. 1992; 44: 377-99.

Hjerten S, Pan H. Purification and characterization of two forms of low affinity $\mathrm{Ca}^{2+}$ ATPase from erythrocyte membranes. Biochem Biophys Acta. 1983; 728: 281-88. http:/ / dx.doi.org/10.1016/0005-2736(83)90480-7

Kelly RA, Smith TW. Pharmacological treatment of heart failure. In: Goodman Gillman's The pharmacological basis of therapeutics. 9th ed. McGraw-Hill, 1996, p 811.

King J. The dehydrogenases or oxidoreductases. Lactate dehydrogenase. In: Practical clinical enzymology. London, Van Nostrand, D. Company Ltd, 1965.

King J. The transferases- alanine and aspartate transaminases. In: Practical clinical enzymology. London, Van Nostrand, D. Company Ltd, 1965.

Kitada Y, Narimatsu A, Suzuki R, Endoh M, Taira N. Does the positive ionotropic action of a novel cardiotonic agent, MCI-154, involve mechanisms other than cyclic AMP? J Pharmacol Exp Ther. 1987; 243: 639-45.

Kokko and Tannen (ed.). Fluid and electrolyte abnormalities of disease. In: Fluids and Electrolytes. $2^{\text {nd }}$ ed. Philadelphia, WB Saunders Company, 1990, pp 647-80.

Lees GH. Inhibition of sodium potassium ATPase: A potentially ubiquitous mechanism contributing to central nervous system neuropathology. Brain Res Rev. 1991; 16: 283-300. http:/ / dx.doi.org/10.1016/ 0165-0173(91)90011-V

McGarry SJ, Williams AJ. Digoxin activates sarcoplasmic reticulum $\mathrm{Ca}^{2+}$ release channels: A possible role in cardiac ionotropy. Br J Pharmacol. 1993; 108: 1043-50.

Muralidharan A, Dhananjayan R. Cardiac stimulant activity of Ocimum basilicum Linn. extracts. Indian J Pharmacol. 2004; 36: $163-66$

Natkarni KM. Indian Materia Medica plants $3^{\text {rd }}$ ed. Vol 1. Bombay, Popular Prakashan, 1976, pp 1009-10.

Ohinishi T, Suzuki T, Suzuki Y, Ozawa K. Comparative study of plasma membrane $\mathrm{Mg}^{2+}$ ATPase activities in normal, regenerating and malignant cells. Biochem Biophys Acta. 1982; 684: 67-74. http://dx.doi.org/10.1016/0005-2736(82) 90050-5

Okinaka S, Kumagi H, Ebashi S, Sugita H, Momoi H, Toyokura $\mathrm{Y}$, et al. Serum creatine phosphokinase. Activity in progressive muscular dystrophy and neuromuscular diseases. Arch Neurol. 1961; 4: 520-25.

Poole-Wilson P, Coluci N, Massie B, Chatterjee K, Coats A. Heart failure: Scientific principles and clinical practices. 
New York, Churchill Livingstone, 1997.

Rathore RS, Prakash A, Singh PP. Preliminary study of antiinflammatory and anti-arthritic activity. Rheumatism 1977; 12: 130.

Tripathi KD. Cardiac glycosides and drugs for CHF. In: Essentials of medical pharmacology, 4th ed. New Delhi, Jaypee Brothers Medical Publishers Pvt. Ltd., 2001, p 120.

Trivedi PC, Nehra S. Herbal drugs and biotechnology, Plant which cures heart disease. Trivedi PC (ed). Jaipur, Pointer
Publishers, 2004, p 3.

Wang SQ, Song LS, Lakatta EG, Cheng H. $\mathrm{Ca}^{2+}$ signaling between single L-type $\mathrm{Ca}^{2+}$ channels and rynodine receptors in heart cells. Nature 2001; 410: 592-96. http:// dx.doi.org/10.1038/35069083 http:// dx.doi.org/10.1038/35066597 http:// dx.doi.org/10.1038/35070620

Yoganarasimhan SN. Medicinal plants of India Tamil Nadu. Vol 2. India, Regional Research Institute Bangalore, 2000, p 441. 